\title{
KONFLIK KERUSUHAN ANTAR SUPORTER SEPAK BOLA DITINJAU DENGAN TEORI DINAMISITAS
}

\author{
Ali Nur'Zain \\ Program Studi Teknik Industri, Fakultas Teknik, \\ Universitas Katolik Widya Mandala Madiun. \\ Email : alinurzain023@gmail.com
}

\begin{abstract}
ABSTRAK
Pada setiap kompetisi pasti terdapat dua kubu yang saling berbeda pemikiran. Hal itu pasti akan menimbulkan tentang perbedaan pendapat bagi setiap kubu. Bagi pendukung ataupun supporter dari jagon yang dipilih pasti akan beradu omongan. Sama halnya dengan pertandingan sepak bola yang terdapat di Indonesia antara Persija Jakarta melawan Persib Bandung. Mengenai peristiwa tersebut pasti akan mejadikan konflik bagi para supporter. Penelitian ini memiliki tujuan untuk mengetahui apakah ada atau tidak perilaku supporter yang memunculkan tindak agresif dan fanatisme. Dalam peristiwa tersebut pastinya dinamika manusia akan terdapat pada dua kubu tersebut. Karena manusia itu adalah subjek jika dilihat melalui dinamika manusia. Setelah dilihat dari dinamika manusia subjek dalam penelitian ini adalah supporter sepak bola yang terdapat dalam dua kubu tersebut. Konflik antara supporter dari tim yang sedang bertanding mengakibatkan kerusuhan antar supporter sepak bola tersubut. Dari kerusuhan itu terdapat korban dari supporter Persija Jakarta karena dikeroyok oleh supporter Persib Bandung.
\end{abstract}

Kata Kunci : Konflik, Dinamika Manusia, Supporter Sepak Bola 


\section{PENDAHULUAN}

Sepak bola merupakan olahraga yang digemari oleh masyarakat Indonesia, selain itu di Indonesia juga sudah terdapat daerah yang memiliki tim sepak bola. Pada setiap tim sepak bola tentunya pasti ada supporter yang siap memberikan dukungan bagi tim yang akan bertanding. Dalam hal ini dapat mencerminkan tentang dinamika, karena dinamika itu memiliki arti yaitu kemampuan dan kekuatan. Selain itu dinamika juga memiliki sifat yang berarti mempunyai kekuatan dan mempunyai daya gerak. Demikian juga manusia, karena manusia juga mempunyai dinamika maka mereka selalu aktif dan selalu berubah. Begitupun dengan supporter sepak bola yang beranggotakan masyarakat pasti juga memiliki dinamika. Supporter yang bangga untuk menjadi pendukung bagi tim sepak bola itu dibentuk agar dapat dijadikan sebagai sebuah kekuatan bagi setiap tim sepak bola. Dengan adanya supporter dapat memberikan daya gerak bagi setiap tim tersebut. Saat tim sedang bertanding supporter memiliki peran penting di dalam pertandingan itu, karena dengan adanya supporter dapat memberikan motivasi bagi tim yang melakukan pertandingan. Selain itu supporter juga berperan sebagai subjek agar dapat menggerakkan dan untuk mencapai kesuksesan terhadap tim sepak bola tersebut. Karena jika ada supporter yang mendukung tim yang sedang bertanding akan menyebabkan pertadingan semakin menarik dan memberikan makna untuk dijadikan sebagai motivasi setiap tim sepak bola tersebut.

Banyak hal yang terjadi di saat ada pertadingan sepak bola, supporter sepak bola bergabung kedalam kelompok supporter memiliki tujuan untuk memberikan dukungan bagi tim yang menjadi kebanggaannya. Mereka juga akan serentak bernyanyi bersama untuk menyanyikan yel-yel dari tim yang didukungnya. Selain bernyanyi mereka juga memakai pakaian yang seragam dan melakukan gerakan yang sesuai intruktur dari supporter tersebut. Pada dasarnya manusia itu berupa dinamika ataupun punya dinamika, hal ini menyatakan bahwa dinamika manusia selalu dalam keaktifan. Supporter sepak bola juga tergolong memiliki dinamika, karena mereka selalu aktif dan mendukung setiap tim yang 
sedang melakukan pertandingan. Dengan mendukung tim kebanggaan mereka supporter sepak bola akan menunjukkan kekompakan mereka untuk menyatukan irama dan semangat agar tim yang sedang bertanding akan mendapatkan kekuatan untuk berjuang dalam pertandingan tersebut.

Para supporter memberikan dukungan bagi tim yang sedang bertanding, mereka menciptakan komunitas-komunitas dan menjalin interaksi sosial untuk memberikan dukungan secara penuh terhadap tim yang menjadi didukung agar dapat memenangkan pertandingan tersebut. Hal itulah yang dapat menimbulkan konflik kerusuhan, karena supporter terkadang terlalu berlebihan dalam mendukung tim pilihannya. Setelah terjadi kerusuhan antar supporter saat dilangsungkannya pertandingan, maka akan terdapat korban yang diakibatkan dari kerusuhan tersebut. Sebenarnya manusia itu adalah makhluk rohani-jasmani. Sesuai dengan kerohaniannya, mereka mempunyai sifat rohani, meskipun tak pernah lepas juga dari kejasmaniannya. Selain rohani-jasmani manusia itu juga merupakan persona atau pribadi. Karena manusia itu persona, maka mereka juga memiliki dinamika dari persona. Persona adalah sesuatu yang betul-betul berdiri sendiri. Karena dinamika manusia itu dinamika dari persona, jadi juga dikuasai olehnya. Setelah itu pada manusia bisa timbul rasa simpati, rasa benci, dan lain sebagaianya, hal itu bisa mereka terima ataupun bisa dia tolak.

Dalam kasus kerusuhan yang terjadi antar supporter sepak bola ini dapat menimbulkan rasa benci pula. Salah satunya adalah pada saat pertandingan antara Persija Jakarta dan Persib Bandung. Dari konflik kerusuhan tersebut terdapat supporter yang meninggal karena dikeroyok oleh supporter tim lain. Persona manusia itu adalah dinamika, maka hal itu berarti persona manusia berkekuatan untuk menjadi lebih sempurna. Mengenai hal itu sebaiknya supporter sepak bola bisa lebih menguasai dirinya untuk tidak menimbulkan kerusuhan. Janganlah melakukan tindakan yang mencerminkan tindak agresif dan fanatisme, karena sebenarnya kita sama-sama warga negara Indonesia tidak perlu melakukan tindakan yang mengakibatkan korban dari konflik kerusuhan antar supporter. Berbeda tim dukungan tidak masalah tetapi kerukunan harus tetap terjaga. 
Berdasarkan penjelasan di atas peneliti akan membahas tentang "Konflik Antar Suporter Sepak Bola". Peneliti berharap dapat memberikan solusi untuk dapat digunakan dalam menyelesaikan permasalahan dalam persepakbolaan yang terdapat di tanah air ini.

\section{LANDASAN TEORI}

\section{Pengertian Konflik}

Konflik berasal dari kata kerja Latin configere yang berarti saling memukul. Secara sosiologis, konflik diartikan sebagai suatu proses sosial antara dua orang atau lebih (bisa juga kelompok) di mana salah satu pihak berusaha menyingkirkan pihak lain dengan menghancurkannya atau membuatnya tidak berdaya. Berdasarkan penjelasan mengenai konflik, kerusuhan antar supporter sepak bola itu terjadi karena mereka memiliki tujuan untuk mencari masalah terhadap supporter dari tim lain. Dengan terdapatnya masalah akan membuat mereka untuk saling mengolok-olok supporter dari tim lain. Kerusuhan antar supporter mengakibatkan perseteruan antar kedua supporter, karena mereka berusaha untuk saling menyingkirkan supporter lain.

\section{Pengertian Dinamika Manusia}

Dinamika manusia berasal dari kata Yunani yang berarti dapat mampu. Dari kata ini dibentuk kata dinamit yang artinya kemampuan, kekuatan. Kita kenal kata dinamit memiliki arti kekuatan ekplosif. Dari kata dinamis dibentuk kata sifat dinamika yang artinya : punya kekuatan, punya daya gerak. Hal tersebut merupakan dinamika yang dilihat dari sudut pandang realitas. Sedangkan jika dilihat dari sudut pandang persona manusia adalah subjek. Hal itu karena manusia merupakan makhluk rohani-jasmani. Dalam pandangan ini bentuk dinamika manusia disebut sebagai panca indera. Mengenai hal tersebut supporter sepak bola dapat memberikan kekuatan terhadap tim yang didukung dalam pertandingan. Dengan adanya supporter tersebut dapat memberikan daya gerak untuk memotivasi tim yang sedang bertanding. Selain itu supporter sepak bola juga bisa 
menjadi sebuah dorongan agar pertandingan sepak bola tersebut menjadi lebih sempurna. Karena pertandingan sepak bola tidak agar menarik jika tidak adanya dukungan dari supporter.

\section{METODOLOGI}

Dalam melakukan penelitian terdapat beberapa tahap yang akan digunakan yaitu tahap identifikasi awal masalah, manusia sebagai realitas, manusia sebagai subjek.

\section{Identifikasi Awal Masalah}

Pada tahap ini terdapat sikap yang masih belum tertib saat supporter sepak bola sedang mendukung tim favoritnya. Mereka mencari konflik dengan cara bertidak agresif dan terlalu fanatik. Dengan tindakan itulah dapat menyebabkan kerusuhan antara supporter dari kedua tim yang sedang bertanding.

\section{Dinamika Manusia Sebagai Realitas}

Pada tahap ini manusia mempunyai dinamika yang selalu aktif maupun bergerak. Begitu pula dengan supporter sepak bola. Mereka selalu melakukan keaktifkan dengan cara mendukung tim favoritnya serta tidak pernah berhenti untuk selalu mensuport tim dukungannya saat sedang bertanding.

\section{Dinamika Manusia Sebagai Subjek}

Pada tahap ini manusia merupakan pribadi rohani-jasmani yang memiliki pendirian dan sikap untuk melihat suatu objek dihadapannya. Begitu pula supporter sepak bola, mereka juga memiliki sikap untuk melihat objek yang sedang dipandanginya, yaitu saat tim favoritnya sedang bertanding membuat supporter terdorong untuk mendukungnya. 


\section{HASIL DAN PEMBAHASAN}

\section{Konflik Pemicu dari Kerusuhan Supporter Sepak Bola}

Kerusuhan pada saat diadakannya pertandingan sepak bola merupakan suatu hal yang sering terjadi pada lingkup sepak bola Indonesia. Awal masalah yang menimbulkan konflik adalah karena terdapat supporter sepak bola yang kurang teratur dan tidak tertib pada saat akan menyaksikan pertandingan. Padahal jika terdapat kerusuhan akan menimbulkan dampak yang dapat menyebabkan korban jiwa. Seperti halnya saat laga pertandingan antara Persija Jakarta dan Persib Bandung. Pada saat pertandingan antara kedua tim tersebut terdapat kerusuhan diantara supporter. Karena adanya kerusuhan dari supporter sepak bola kedua tim tersebut, terdapat korban jiwa dari supporter Persija Jakarta. Hal itu terjadi karena ada salah satu supporter Persija Jakarta yang dikeroyok oleh supporter Persib Bandung. Supporter sepak bola dari kedua tim terlalu agresif dan fanatik, sehingga mereka melakukan kerusuhan pada saat diadakannya pertandingan antara Persija Jakarta dan Persib Bandung.

\section{Realitas Kerusuhan Supporter Sepak Bola}

Supporter sepak bola yang sedang menyaksikan pertandingan karena tim favoritnya sedang bertanding selalu aktif untuk memberikan support terhadap tim favoritnya. Sebenarnya mendukung tim favorit itu baik dan dapat memberikan kekuatan bagi tim yang sedang bertanding, tetapi supporter malah melakukan tindak agresif. Setelah melakukan tindak agresif mereka juga mencari-cari konflik agar suasana di sekitar supporter menjadi ricuh. Padahal jika terdapat konflik di antara supporter satu dengan supporter lainnya akan dapat memberikan dampak kerusuhan di antara supporter tersebut. Setelah terjadi kerusuhan pastinya juga akan menimbulkan korban jiwa. Seharusnya supporter sebaiknya mampu memberikan kekuatan untuk menggerakkan dan mendorong untuk mencapai menuju hal yang lebih baik. Tetapi pada realitasnya supporter sepak bola malah melakukan tindakan yang fanatik dan mengakibatkan kerusuhan. 


\section{Subjek dari Kerusuhan Supporter Sepak Bola}

Supporter sepak bola yang sedang mendukung tim favoritnya di pertandingan tersebut merupakan subjek dari sebuah kerusuhan itu. Karena supporter sepak bola juga memiliki sikap yang berdasarkan kehendaknya. Pada saat supporter sepak bola menyaksikan tim favoritnya yang sedang bertanding, mereka nantinya akan memiliki keinginan untuk membuat suasana di pertandingan menjadi seru dan menarik. Tetapi cara mereka mengubah suasana di pertandingan dengan cara mencari konfik dari supporter tim lain. Padahal konflik dari supporter satu dengan supporter lainnya dapat menimbulkan rasa benci jika mereka tidak bisa mengontrol dirinya. Dampak dari rasa benci yang tidak bisa terkontrol dari dirinya kemungkinan nantinya akan menimbulkan kerusuhan di antara supporter satu dengan supporter lainnya. Seharusnya dengan adanya supporter pada saat diadakan pertandingan sepak bola dapat memberikan dorongan untuk menunjukkan tindak suportivitas diantara kedua tim tersebut. Akan tetapi supporter sepak bola malah menmbuat kerusuhan dengan melakukan tindakan agresif dan fanatik. Sehingga efek dari tindakan tersebut dapat mengakibatkan korban jiwa pada saat terjadinya kerusuhan.

\section{KESIMPULAN}

Konflik kerusuhan antara supporter sepak bola merupakan suatu persoalan yang dapat korban jiwa. Kerusuhan terjadi karena terdapat supporter yang melakukan tindakan yang agresif dan fanatik, sehingga menimbukan dampak yang dapat membuat sebuah pertandingan menjadi tidak tertib. Pada dasarnya supporter sepak bola seharusnya dapat menjadi sebuah kekuatan bagi tim yang sedang bertanding agar tim tersebut dapat berusaha dengan maksimal di dalam pertandingan. 


\section{DAFTAR PUSTAKA}

https://sport.detik.com/sepakbola/liga-indonesia/d-4234713/antisipasi-kerusuhanantar-suporter-undang-undang-khusus-perlu-dibuat

https://www.bola.com/indonesia/read/3655061/konflik-suporter-indonesiamuncul-akibat-gerakan-yang-belum-terstruktur-dan-rapi

Dewantara, A. (2017). Filsafat Moral (Pergumulan Etis Keseharian Hidup Manusia). 